\title{
Predictors of gallstone formation after bariatric surgery: a multivariate analysis of risk factors comparing gastric bypass, gastric banding, and sleeve gastrectomy
}

Vicky Ka Ming Li • Nestor Pulido •

Patricio Fajnwaks · Samuel Szomstein •

Raul Rosenthal · Pedro Martinez-Duartez

Published online: 3 April 2009

(C) Springer Science+Business Media, LLC 2009

Erratum to: Surg Endosc

DOI 10.1007/s00464-008-0204-6

Pedro Martinez-Duartez was inadvertently omitted from the list of authors.

The online version of the original article can be found under doi:10.1007/s00464-008-0204-6.

V. K. M. Li · N. Pulido · P. Fajnwaks · S. Szomstein ·

R. Rosenthal $(\bowtie) \cdot$ P. Martinez-Duartez

Section of Minimally Invasive and Endoscopic Surgery,

The Bariatric and Metabolic Institute at Cleveland Clinic

Florida, Cleveland Clinic Florida, 2950 Cleveland Clinic Blvd,

Weston, FL 33331, USA

e-mail: rosentr@ccf.org 